\title{
Comparison effects of decapitation and disbudding with application of glucose in rooting of Chrysanthemum cuttings
}

\section{EDWARD BOROWSKI and LIDIA KOZLOWSKA}

Institute of Natural Principles of Plant Production, Agricultural University, Akademicka 15, 20-934 Lublin, Poland

(Received: May 24, 1983)

\begin{abstract}
Cuttings of Chrysanthemum cv. 'Horim Golden' were decapitated and disbudded or intact cuttings were treated with glucose solution. Both treatments were carried out at different times after excision of the cuttings. Removal of buds on the day of cuttings excision delayed the appearance of first visible roots on the cuttings and significantly decreased the number of formed roots. But this treatment performed beetwen day 3-5 significantly increased the mean number of roots on the cuttings. A similar influence as that of disbudding was obtained by glucose treatment of the cuttings, especially their basal parts.
\end{abstract}

\section{INTRODUCTION}

As early as 1925 Van der Leek 〈after E r i k s e n, 1973〉 reported that, when all buds were removed from cuttings of Populus, Salix and Ribes, root formation was strongly reduced. The same effect of disbudding of cuttings has also been noted by $\mathrm{H}$ a r a d a and $\mathrm{N} \mathrm{a} \mathrm{k}$ a y a m a $\langle 1958\rangle$ with tea cuttings and by $\mathrm{F} \mathrm{a} \mathrm{d} 1$ and $\mathrm{Har} \mathrm{tm}$ a $\mathrm{n}\langle 1967\rangle$ with pear cuttings.

E riks e $n<1973\rangle$ showed that decapitation and disbudding of pea cuttings within the first 4 days after cutting drastically reduces both the number of rooted cuttings and the number of roots per cutting. Treatment 5 to 6 days after excision of the cuttings has no effect on root formation or the number of roots per cutting. An adverse effect of decapitation and disbudding in a similar experiment with Chrysanthemum cuttings was obtained by $\mathrm{F}$ i s c h e $\mathrm{r}$ and $\mathrm{H}$ a $\mathrm{n} \mathrm{se} \mathrm{n}$ $\langle 1977\rangle$. Removal of the buds on the day of excision of the cuttings had no effect on the number of roots formed, while removal of buds on day 2 to day 5 after excision had a promotive effect.

The present paper is concerned with the effects on root formation of decapitation and disbudding or exogenously supplied glucose at different times 
after taking the cuttings. When, instead of removing the apical bud exogenous glucose was introduced information might be obtained, why decapitation and disbudding of Chrysanthemum cuttings had a promotive effect on their rooting. Both treatments at different times after excision of the cuttings could also give information as to when decapitation or application of carbohydrates is most effective.

\section{MATERIAL AND METHODS}

Stock plants - Cuttings of the Chrysanthemum cv. 'Horim Golden' were planted in peat and rooted at $20^{\circ} \mathrm{C}$ in the greenhouse. When the cuttings rooted, three of them were planted in each 7-1 Mitscherlich pot. They were grown in a growth room under supplementary light from alternately arranged white and red fluorescent lamps. The illumination was $30 \mathrm{Wm}^{-2}$ at plant level. The growing-medium was a mixture of peat and sand $\langle 2: 1 \mathrm{v} / \mathrm{v}\rangle$. The plants were watered every second day and fertilized every week. The air temperature was $20^{\circ} \mathrm{C}$, relative humidity $70 \%$ and the photoperiod $14 \mathrm{~h}$.

\section{EXPERIMENT 1}

Cuttings of about $5 \mathrm{~cm}$ and with 3-4 fully developed leaves were taken from the stock plants after 4 weeks of growth. All suitable cuttings, from the stock plants were excised. Cuttings grown during the next 4 weeks were used for a second replications of this experiment. They were placed in 1-cm thick insulation plates $\langle$ isopor > with holes for the cuttings. The plates were floated in $10 \mathrm{~cm}$ deep plastic trays filled with distilled water. The trays were placed in a growth room, where the rooting-conditions were exactly the same as for the stock plants, except for the illumination which was approx. $15 \mathrm{Wm}^{-2}$.

The cuttings were decapitated and disbudded simultaneously excision $\langle 0\rangle$ or after 1,2,3,5,7 days of rooting. The treatment was limited to the first week of the rooting period, because in earlier investigation $\langle\mathrm{B}$ o r o w s k i et al., 1981 $\rangle$ it was found that roots emerge through the epidermis seven days after removal of the cuttings from the stock plant. Decapitation was performed by removing only the uppermost $0.5 \mathrm{~cm}$ of each cutting, while disbudding included the removal of all lateral buds by means of a scalpel. Each treatment comprised 2 replications of 40 cuttings each.

During the period of root formation, the rooted cuttings were counted at intervals. The number of roots per cutting, the length of the longest root, and the fresh and dry weight of roots were recorded at the end of the rooting-period of 21 days, irrespective of the time of treatment.

EXPERIMENT 2

The growing conditions for stock plants were the same as described in Experiment 1. 
Cuttings were taken from the stock plants after 4 weeks of growth. The rooting-conditions of cuttings were exactly the same as described in Experiment 1 . During the rooting period the intact cuttings were supplied with an aqueous solution of glucose in $5^{-} \times 10^{-3} \mathrm{M}$ concentration. Each times about of 0.02-0.03 $\mathrm{ml}$ of glucose solution 〈distilled water for the control〉 were supplied into a stock of cuttings by means of a syringe.

The experiments consisted of two experimental series. One series of cuttings received glucose $1 \mathrm{~cm}$ above the base, the second series $1 \mathrm{~cm}$ below the top of the cutting. The first injection of glucose was made immediately after excision of the cuttings $\langle 0\rangle$ or after $2,3,5,7$ days of rooting. The next injection was made each day until the beginning of the root initiation process. Each treatment comprised 2 replications of 30 cuttings each. The rooting-period was 21 days. Observations on rooting were the same as described in Experiment 1. During the rooting-period, the water in both experiments was aerated by air pumps, and the cuttings were regularly sprayed with distilled water. The results of analyses were subjected to analysis of variance and Student's t-test was used to evaluate the differences between the means at the probability level $\mathrm{P}=95 \%$.

\section{RESULTS}

EFFECT OF DECAPITATION AND DISBUDDING OF CUTTINGS

Decapitation and disbudding of the cuttings except treatment carried out simultaneously with the excision of the cuttings reduced the number of days necessary for the appearance of the first visible roots 〈Table 1〉. Cuttings decapitated and disbudded on day 1 to 3 after the beginning of the rooting-period were characterized by a fast root initiation process, they reached full rooting

Table 1

Effect of decapitation and disbudding of Chrysanthemum cuttings at different time intervals after cutting on percentage of rooted cuttings

\begin{tabular}{|c|c|c|c|c|c|c|c|c|c|c|}
\hline \multirow{2}{*}{\multicolumn{2}{|c|}{$\begin{array}{l}\text { Time of decapitation } \\
\text { and disbudding } \\
\text { after cutting } \\
\text { (days) }\end{array}$}} & \multicolumn{9}{|c|}{ Percentage of rooted cuttings after days } \\
\hline & & 6 & 7 & 8 & 9 & 10 & 11 & 12 & 13 & 14 \\
\hline & $\mathbf{0}$ & $\mathbf{3} \mathbf{3}$ & 8,3 & 25.0 & 40.0 & 65.0 & 91.7 & 93.3 & 98.3 & 100.0 \\
\hline & 1 & 11.7 & 23.3 & 45.0 & 66.7 & 86.7 & 100.0 & & & \\
\hline & 2 & 13.3 & 26.7 & 56.7 & 78.3 & 88.3 & 100.0 & & & \\
\hline & 3 & 15.0 & 36.7 & 61.7 & 83.3 & 98.3 & 100.0 & & & \\
\hline & 5 & 1.7 & 6.7 & 43.3 & 75.0 & 95.0 & 98.3 & 100.0 & & \\
\hline & 7 & 3.3 & 10.0 & 36.7 & 61.7 & 86.7 & 98.3 & 100.0 & & \\
\hline $\begin{array}{l}\text { Control - } \\
\text { cutting }\end{array}$ & - intact & 6.7 & 20.0 & 26.7 & 51.7 & 71.7 & 91.7 & 95.0 & 100.0 & \\
\hline
\end{tabular}


about 2 days earlier than did intact ours $\langle$ Control $\rangle$. Cuttings treated on day 5 and 7 formed first roots more slowly than the previous ones and full rooting was reached one day later. If the treatments were carried out immediately after excision the root initiation process was slower than that in intact cuttings. They were rooted in $100 \% 3$ days later than those treated on day 1 to day 3 , and 1 day later than in the control.

Decapitation and disbudding of the cuttings had a significant influence on the number of roots after a rooting-period of 3 weeks $\langle$ Table 2$\rangle$. Treatment carried out at the time of making cuttings $\langle 0$ day $\rangle$ significantly decreased the number of roots per cutting, while decapitation and disbudding 1 and 2 days after cutting had no effect. When the same treatment was given on day 3 to day 7 <after the beginning of the rooting-period $\rangle$, the number of formed roots significantly increased.

Table 2

Effect of decapitation and disbudding of Chrysanthemum cuttings at different time intervals after cutting on the number of roots, root length, fresh and dry weight of roots after a rooting period of 21 days

\begin{tabular}{ccccc}
\hline $\begin{array}{c}\text { Time of decapitation } \\
\text { and disbudding } \\
\text { after cutting } \\
\text { (days) }\end{array}$ & $\begin{array}{c}\text { Number of } \\
\text { roots per } \\
\text { cutting }\end{array}$ & $\begin{array}{c}\text { Length of } \\
\text { longest root, of roots, in } \\
\text { in per } \\
\text { cutting }\end{array}$ & $\begin{array}{c}\text { Fresh weight } \\
\text { mg put } \\
\text { cutting }\end{array}$ & $\begin{array}{c}\text { Dry weight } \\
\text { of roots, } \\
\text { ing per } \\
\text { cutting }\end{array}$ \\
\hline & & & & \\
1 & 28.5 & 8.4 & 299.2 & 22.9 \\
2 & 35.8 & 9.3 & 376.7 & 27.1 \\
3 & 39.8 & 8.9 & 384.0 & 28.2 \\
5 & 46.0 & 8.3 & 385.1 & 31.5 \\
7 & 44.0 & 8.4 & 380.8 & 27.7 \\
Control - intact & 42.1 & 8.4 & 377.0 & 27.7 \\
cuttings & 37.0 & 8.5 & 339.1 & 22.1 \\
\hline LSD at P=95\% & 5.52 & N.S. & 41.86 & 4.24 \\
\hline
\end{tabular}

Table 2 shows that the time of decapitation and disbudding of the cuttings had a significant influence on fresh and dry weight of the roots, but no significant influence on root length.

\section{EFFECT OF EXOGENOUS APPLICATION OF GLUCOSE INTO THE CUTTINGS}

Exogenously supplied glucose to the basal parts of cuttings had a higher influence on their rooting, than glucose treatment of the top parts. 〈Fig. 1〉.

The time of beginning of exogenous glucose supply to both parts of cuttings had no significant effect on the number of days necessary for the appearance of 


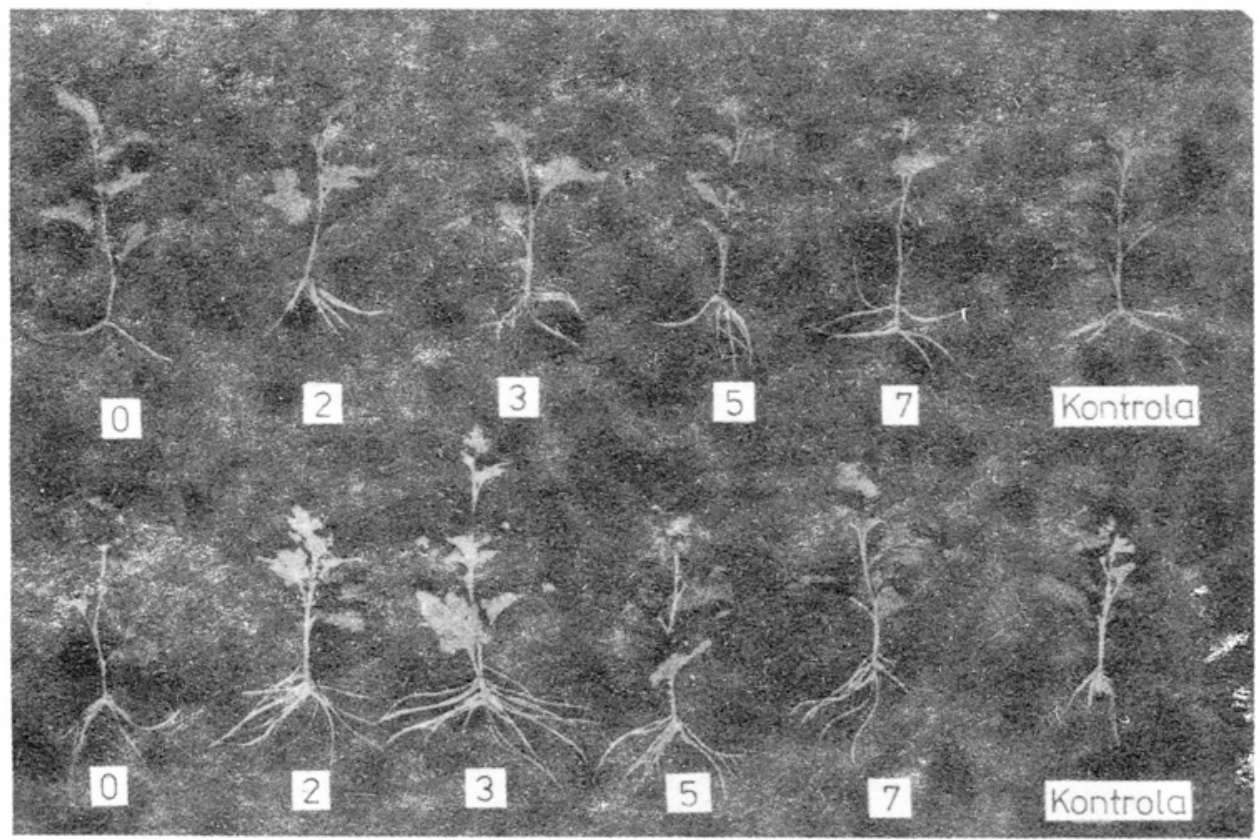

Fig. 1. Effect of exogenous application of giucose into cuttings on their rooting. Above: Rooted cuttings top parts of which were treated with glucose. Below: Rooted cuttings basal parts of which were treated with glucose. $0 ; 2 ; 3 ; 5 ; 7$; days of glucose injection after cutting. Control - cuttings on right side were treated with water

$$
\text { T a b l e } 3
$$

Effect of glucose injection in to basal or top part of Chrysanthemum cuttings at different time intervals after cutting on percentage of rooted cuttings

Time of glucose injection after cutting (days)
Percentage of rooted cuttings after days

\begin{tabular}{lllllll}
\hline 6 & 7 & 8 & 9 & 10 & 11 & 12
\end{tabular}

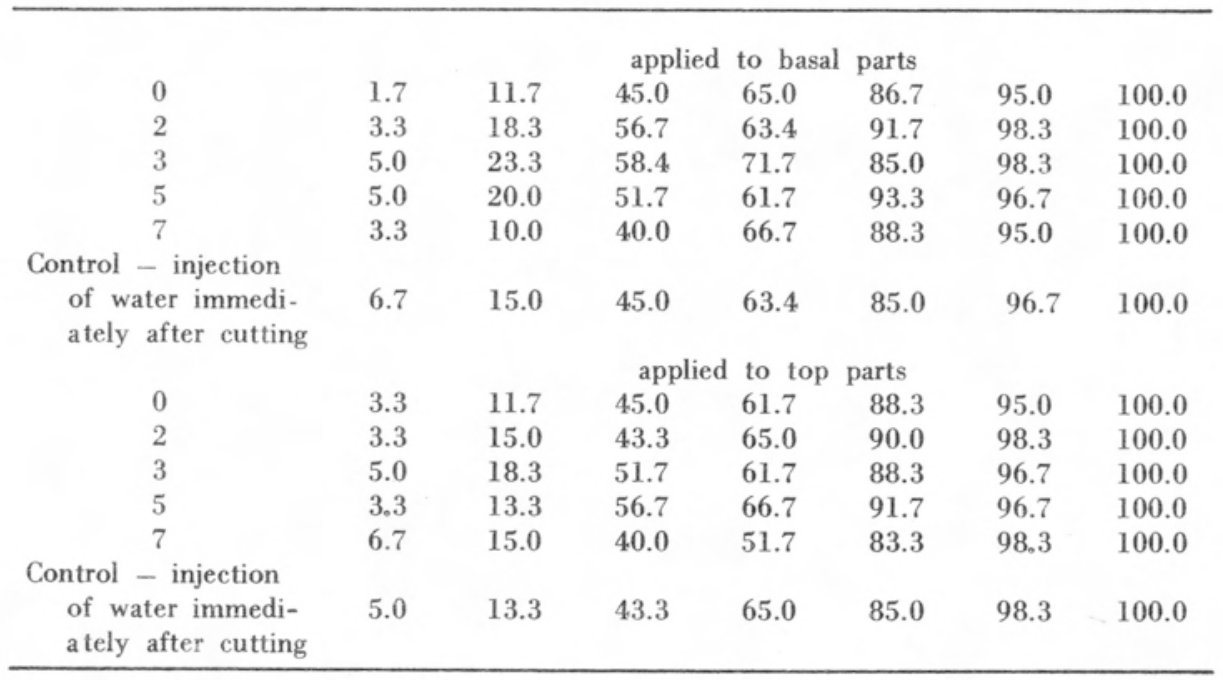


$\mathrm{T}$ a b I e 4

Effect of glucose injection in to basal or top part of Chrysanthemum cuttings at different time intervals after cutting on the number of roots, root length, fresh and dry weight of roots after a rooting period of 21 days

\begin{tabular}{|c|c|c|c|c|}
\hline $\begin{array}{l}\text { Time of glucose } \\
\text { injection after } \\
\text { cutting } \\
\text { (days) }\end{array}$ & $\begin{array}{l}\text { Number of } \\
\text { roots per } \\
\text { cutting }\end{array}$ & $\begin{array}{l}\text { Length of } \\
\text { longest root, } \\
\text { in cm per } \\
\text { cutting }\end{array}$ & $\begin{array}{c}\text { Fresh weight } \\
\text { of roots, in } \\
\text { mg per } \\
\text { cutting }\end{array}$ & $\begin{array}{l}\text { Dry weight } \\
\text { of roots, } \\
\text { in } \mathrm{mg} \text { per } \\
\text { cutting }\end{array}$ \\
\hline & \multicolumn{3}{|c|}{ applied to basal parts } & \\
\hline $\mathbf{0}$ & 47.4 & 9.8 & 465.8 & 34,1 \\
\hline 2 & $\mathbf{5 7 . 4}$ & 10.5 & 570.9 & 39.5 \\
\hline 3 & 66.3 & 11.3 & 615.8 & 43.5 \\
\hline 5 & 55.5 & 10.7 & $\mathbf{5 6 1 . 5}$ & 39.6 \\
\hline 7 & 49.3 & 10.8 & 513.8 & 35.8 \\
\hline $\begin{array}{l}\text { Control - injection } \\
\text { of water immedi- } \\
\text { ately after cutting }\end{array}$ & 45.1 & 10.3 & 467.5 & 34.7 \\
\hline \multirow[t]{2}{*}{$\mathrm{LSD}$ at $\mathrm{P}=95 \%$} & 6.97 & N.S. & 37.85 & 1.72 \\
\hline & \multicolumn{3}{|c|}{ applied to top parts } & \\
\hline $\mathbf{0}$ & 39.0 & 7.0 & 359.3 & 23.6 \\
\hline 2 & 39.7 & 7.7 & 391.3 & 22.9 \\
\hline 3 & 49.1 & 7.9 & 430.1 & 28.0 \\
\hline 5 & 43.8 & 7.8 & 369.2 & 21.8 \\
\hline 7 & 35.6 & 6.2 & 263.5 & 14.1 \\
\hline $\begin{array}{l}\text { Control - injection } \\
\text { of water immedi- } \\
\text { ately after cutting }\end{array}$ & 40.2 & 6.4 & 403.7 & 23.3 \\
\hline LSD at $\mathbf{P}=\mathbf{9 5} \%$ & 5.60 & N.S. & 64.93 & 4.07 \\
\hline
\end{tabular}

visible roots $\langle$ Table 3$\rangle$. Glucose treatment of the basal parts of cuttings had a significant stimulatory effect on the number of roots after a 21-day rooting period 〈Table 4, Fig. 1 >. Start of glucose supply to the cuttings on day 2 to day 5 after the beginning of the rooting-period significantly increased the number of roots per cutting. Glucose treatment of cuttings immediately after excision, or later than 5 days after cutting had no significant influence on the number of formed roots. Glucose supplied to the top parts of cuttings had a slight effect on the number of roots. Only an injection of glucose started 3 days after cutting significantly increased the number of formed roots.

The time of glucose supply had no significant effect on the length of the longest root, but a glucose injection to the basal parts of cuttings distinctly increased the length of roots in comparison to the length of roots on cuttings 
treated in the top parts $\langle$ Table 4, Fig. 1 $\rangle$. Table 4 shows that the time and place of glucose application to the cuttings had also a significant influence on fresh and dry weight of the roots.

\section{DISCUSSION}

Decapitation and disbudding of Chrysanthemum cuttings carried out on day 3 to day 7 after the beginning of the rooting-period resulted in a high number of roots per cutting and fewer days necessary for the appearance of visible roots. Similar results were found in the Chrysanthemum 'Improved Mefo' $\langle\mathbf{F}$ i s c h e $r$ and $\mathrm{H}$ a $\mathrm{n}$ s e $\mathrm{n}, 1977\rangle$. However an adverse effect of decapitation and disbudding has been reported for other plant species, e.g. Salix, Populus and Ribes $\langle$ Van der Leek $\langle 1925\rangle$ after E r i k s n, 1973〉, tea $\langle\mathrm{H} \mathrm{a} \mathrm{r} \mathrm{a} \mathrm{d} \mathrm{and}$ $\mathrm{N}$ a k a y a $\mathrm{m} \mathrm{a}, 1958\rangle$, pear $\langle\mathrm{F}$ a d 1 and $\mathrm{H}$ a r t $\mathrm{m}$ a $\mathrm{n} \mathrm{n}, 1967\rangle$ and pea $\langle\mathrm{E} \mathrm{r} \mathrm{i} \mathrm{k} \mathrm{s} \mathrm{e} \mathrm{n,} \mathrm{1973 \rangle .} \mathrm{The} \mathrm{positive} \mathrm{influence} \mathrm{of} \mathrm{these} \mathrm{treatments} \mathrm{on} \mathrm{rooting} \mathrm{of}$ Chrysanthemum cuttings, and negative on rooting of other plant species is difficult to explain. Beside removing an important source of auxin, simultaneously a sink for carbohydrates is removed. It is, therefore, possible that the stimulatory effect of decapitation on rooting of Chrysanthemum cuttings might be caused by the increased level of carbohydrates. This hypothesis is supported by the results obtained with exogenously supplied glucose $\langle$ Table 4$\rangle$. The results show that application of carbohydrates to intact cuttings had the same influence on their rooting as did decapitation and disbudding. Furthermore, the results obtained in experiment 2 indicate that the apical shoot meristem of Chrysanthemum cuttings was a big sink for carbohydrates. It was remarkable that the effect of glucose supplied to the basal part of cuttings on the number of formed roots was more effective than that of glucose supplied to the top parts. So different an influence of decapitation and disbudding on rooting of Chrysanthemum cuttings and cuttings of other plant species indicates that carbohydrates in Chrysanthemum cuttings may be a limiting factor. This hypothesis is supported by the results concerning, the role of stock-plant irradiation and carbohydrates on adventitious root formation. High irradiation of the stock plants or the application of carbohydrates to the cuttings severely inhibited root formation in many plant species, e.g. Sinapis and radish $\langle\mathrm{M}$ o o r e et al., 1972; L o v e 11 et al., 1974〉, pea $\langle\mathrm{H}$ a n s e n, 1976; V e i e r s k ov, 1978; R a ja go pal and A nd e r se n, 1980; R a s m us se $n$ and A n d e r s e n, 1980 $\rangle$, dahlia $\langle\mathrm{B}$ i r a $\mathrm{n}$ and $\mathrm{H}$ a l e v y, 1973〉, Pinus $\langle\mathrm{H}$ a n s e $\mathrm{n}$ et al., 1978〉, Salix $\langle$ E li a s s on and B r u e s, 1980〉 and Hibiscus $\langle\mathrm{K} \mathrm{a} \mathrm{c} \mathrm{h} \mathrm{e} \mathrm{c} \mathrm{h} \mathrm{e} \mathrm{b} \mathrm{a,}$ 1976 , while high irradiation of Chrysanthemum stock plants stimulated rooting of their cuttings $<\mathrm{F} \mathrm{i} \mathrm{s} \mathrm{h} \mathrm{e} \mathrm{r} \mathrm{and} \mathrm{H}$ a n s e n, 1977; B or ow s k et al., $1981\rangle$. The present results aslo show that application of carbohydrates to Chrysanthemum cuttings clearly promoted their rooting. 
The highest number of formed roots after decapitation or application of glucose, which started 3 days after excision of the cuttings suggests that the process of root meristem formation was at this time most intensive. Therefore, the carbohydrate content in the cuttings increased by both treatments influenced best their rooting. Later root initiation was presumably less intensive, therefore, the effect of decapitation or application of glucose was smaller too. The inhibition of root formation when decapitation was carried out immediately after excision of the cuttings or when application of glucose was started at the same time, led presumably to a supraoptimal concentration of carbohydrates in relation to the auxin level. Supporting results for this hypothesis were found in the work by $\mathrm{N}$ a n d a et al. $\langle 1971\rangle$ and by G re e n w o o d and B e r l y n $\langle 1973\rangle$, who demonstrated an interaction beetween auxin and carbohydrates.

\section{REFERENCES}

B i r a n I., H a 1 e v y A. H., 1973. Stock plant shading and rooting of dahlia cuttings. Scientia Hortic. 1: 125-131.

B o r ows k i E., H a ge n P., M o e R., 1981. Stock plant irradiation and rooting of chrysanthemum cuttings in light or dark. Scientia Hortic. 15: 245-253.

E 1 i a s s o n L., B r u n e s L., 1980. Light effects on root formation in aspen and willow cuttings. Physiol. Plant. 48: 261-265.

E r i k s e n E. N., 1973. Root formation in pea cuttings. I. Effects of decapitation and disbudding at different developmental stages. Physiol. Plant. 28: 503-506.

F a d 1 M. S., H a r t m a n n H. T., 1967. Relationship between seasonal changes in endogenous promotors and inhibitors in pear buds and cutting bases and the rooting of pear hardwood cuttings. Proc. Am. Soc. Hortic. Sci. 91: 96-112.

F i s c h e r P., H a n s e n J., 1977. Rooting of chrysanthemum cuttings. Influence of irradiance during stock plant growth and of decapitation and disbudding of cuttings. Scientia Hortic. 7: 171-178.

G r e e n w o od M. S., B e $r 1$ y n G. P., 1973. Sucrose indole-3-acetic acid interactions on root regeneration by Pinus lambertiana embryo cuttings. Am. J. Bot. 60: 42-47.

$\mathrm{H}$ a $\mathrm{n}$ s e $\mathrm{n}$ J., 1976. Adventitious root formation induced by gibberellic acid and regulated by the irradiance to the stock plants. Physiol. Plant. 36: 77-81.

H a n s e n J., S t r o m qu is t L. H., E r i c s s o n A., 1978. Influence of the irradiance on carbohydrate content and rooting of cuttings of pine seedlings $\langle$ Pinus silvestris L.〉. Plant Physiol. 61: 975-979.

$\mathrm{H}$ a r a d a S., $\mathrm{N}$ a $\mathrm{k}$ a $\mathrm{y}$ a $\mathrm{m}$ a $\mathrm{A} ., 1958$. The influence of the bud and leaf on root formation in tea-cuttings. Study of Tea. 19: 1-4. 〈Hortic. Abstr. 1959, vol. 29: 3051〉.

$\mathrm{K}$ a $\mathrm{c} \mathrm{h}$ e $\mathrm{ch}$ e b a J. L., 1976. Seasonal effects of light and auxin on the rooting of Hibiscus cuttings. Scientia Hortic. 5: 345-351.

L o v e 11 P.H., I 11 s I e y A., M o o r e K.G., 1974. Endogenous sugar levels and their effects on root formation and petiole yellowing of detached mustard cotyledons. Physiol. Plant. 31: 231-236.

M o o r e K. G., C o b b A., L o ve 11 P. H., 1972. Effects of sucrose on rooting and senescence in detached Raphanus sativus L. cotyledons. J. Exp. Bot. 23: 65-74.

$\mathrm{N}$ a n d a K. K., J a i n M. K., M a $1 \mathrm{~h}$ o t $\mathrm{r}$ a S., 1971. Effect of glucose and auxin in rooting etiolated stem segments of Populus nigra. Physiol. Plant. 24: 387-391. 
R a j a g o p a 1 V., A n d e r s e n A. S., 1980. Water stress and root formation in pea cuttings. I. Influence of the degree and duration of water stress on stock plants grown under two levels of irradiance. Physiol. Plant. 48: 144-149.

R a s $\mathrm{m} \mathrm{u} s \mathrm{~s}$ e $\mathrm{n}$ S., A n d e r s e n A. S., 1980. Water stress and root formation in pea cuttings. II. Effect of abscisic acid treatment of cuttings from stock plants grown under two levels of irradiance. Physiol. Plant. 48: 150-154.

V e i e r s k o v B., 1978. A relationship between length and adventitious root formation in pea cuttings. Physiol. Plant. 42: 146-150.

Porównanie wpływu usuwania pąka głównego i pąków bocznych ze stosowaniem glukozy w ukorzenianiu sadzonek złocienia ogrodowego

\section{St reszcze n i e}

Sadzonkom złocienia ogrodowego odmiany 'Horim Golden' usuwano pąki główne i pąki boczne lub traktowano je roztworem glukozy. Celem prowadzon ych zabiegów była próba określenia funkcji merystemu wierzchołkowego i merystemów bocznych w procesie ukorzeniania sadzonek złocieni. Oba zabiegi były przeprowadzone w różnych terminach po ścięciu sadzonek.

Usuwanie merystemów w dniu cięcia sadzonek wplywało na obniżanie liczby oraz opóźnienie inicjacji pierwszych korzeni, natomiast zabieg ten wykonany pomiędzy trzecim a piątym dniem ukorzeniania powodował zwiększanie liczby korzeni na sadzonkach.

Traktowanie sadzonek roztworem glukozy, rozpoczęte w dniu ich cięcia, oddziaływało ujemnie na liczbę formowanych korzeni. Podawanie zaś glukozy rozpoczęte pomiędzy trzecim a piątym dniem ukorzeniania wpływało na istotne zwiększenie liczby formowanych korzeni, nie miało natomiast wpływu na czas ich inicjacji. 